\title{
Review \\ Clinical Implications of Growth Hormone Deficiency for Oral Health in Children: A Systematic Review
}

\author{
Natalia Torlińska-Walkowiak ${ }^{1, * \mathbb{C}}$, Katarzyna Anna Majewska $^{2}{ }^{\mathbb{D}}$, Andrzej Kędzia ${ }^{2}$ \\ and Justyna Opydo-Szymaczek ${ }^{1}{ }^{10}$ \\ 1 Department of Pediatric Dentistry, Poznan University of Medical Sciences, Bukowska 70, \\ 60-812 Poznan, Poland; jopydo@ump.edu.pl \\ 2 Department of Clinical Auxology and Pediatric Nursing, Poznan University of Medical Sciences, \\ Szpitalna 27/33, 60-572 Poznan, Poland; katarzynamajewska@ump.edu.pl (K.A.M.); \\ akedzia@ump.edu.pl (A.K.) \\ * Correspondence: ntw@umed.poznan.pl; Tel.: +48-618-547-053
}

Citation: Torlińska-Walkowiak, N.;

Majewska, K.A.; Kędzia, A.;

Opydo-Szymaczek, J. Clinical

Implications of Growth Hormone

Deficiency for Oral Health in

Children: A Systematic Review. J.

Clin. Med. 2021, 10, 3733. https://

doi.org/10.3390/jcm10163733

Academic Editor: Emmanuel Andrès

Received: 29 May 2021

Accepted: 17 August 2021

Published: 22 August 2021

Publisher's Note: MDPI stays neutral with regard to jurisdictional claims in published maps and institutional affiliations.

Copyright: (c) 2021 by the authors. Licensee MDPI, Basel, Switzerland. This article is an open access article distributed under the terms and conditions of the Creative Commons Attribution (CC BY) license (https:// creativecommons.org/licenses/by/ $4.0 /)$.

\begin{abstract}
Growth hormone $(\mathrm{GH})$ is involved in the regulation of the postnatal dental and skeletal growth, but its effects on oral health have not been clearly defined. This paper aims to provide a review of current clinical knowledge of dental caries, tooth wear, developmental enamel defects, craniofacial growth and morphology, dental maturation, and tooth eruption in growth hormone deficient (GHD) children. A systematic review was carried out using Scopus, MEDLINE-EbscoHost and Web of Science from 2000 to May 2021. PRISMA guidelines for reporting systematic reviews were followed. All the selected studies involved groups under eighteen years of age, covering a total of 465 GHD patients. The studies that were selected provide reliable evidence for delayed dental maturity and orthodontic disturbances in GHD patients. Data on dental hard tissues pathology are scarce and are limited to occurrences of dental caries. GHD children showed abnormal craniofacial morphology with reduced mandibular dimensions, with a resulting tendency towards Angle's Class II occlusion, which affected up to $31 \%$ of patients. Dental age has been shown to be delayed in GHD patients by about 1 to 2 years. Moreover, the risk of dental caries in children with GHD decreases with increasing levels of vitamin D. Hence, further studies would be valuable for evaluating the risk of various oral health problems and to organize targeted dental care for this vulnerable group.
\end{abstract}

Keywords: growth hormone deficiency; children; caries; dental maturation; craniofacial growth/ morphology; tooth wear; enamel defects

\section{Introduction}

Tooth development and eruption, as essential parts of general development, are examples of processes that can be easily disturbed. It is well known that the development of the alveolar bone surrounding the tooth germs is closely coordinated with tooth morphogenesis. At the same time, eruption also depends on precisely regulated bone remodeling [1,2].

Growth hormone $(\mathrm{GH})$ is a critical regulator of the growth process in children. It is secreted by the pituitary gland, mainly during physiological night sleep. GH exerts its function mainly by promoting insulin-like growth factor I (IGF-I) secretion, acting within the GH-IGF-I signaling axis [3,4].

Despite numerous studies and the seemingly clear effect of GH on dental development, this process is still not well understood [5]. Research indicates that growth hormone action is associated with tooth maturation and eruption [6,7]. GH is able to induce proliferation of epithelial stem cells in molar buds, along with preameloblast differentiation and enamel formation [8,9]. GH and IGF-I induce the production of morphogenetic proteins 2 and 4 (BMP-2, BMP-4) and of the transforming growth factor-beta superfamily, affecting odontoblast differentiation and osteodentin and tubular dentine formation $[8,10,11]$. Furthermore, 
it has been shown that $\mathrm{GH}$ affects cellular cementum in mice [12,13]. GH, GH receptor, and IGF binding proteins are detected during particular phases of tooth development, at the bud stage, cup stage and bell stage, affecting the tooth shape and size $[8,14]$.

Both, cell sensitivity to $\mathrm{GH}$ and the site of $\mathrm{GH}$ action are closely coordinated and affect the odontogenesis. When the new matrix begins to form, GH receptors are expressed in tooth tissues and mediate local growth responses. However, cementocytes and mature odontoblasts in later stages of tooth development do not display expression, which suggests that they become insensitive [3].

Recent studies have shown that IGF-I and its receptor are expressed in both dental epithelial and mesenchymal tissues of tooth germs, increasing the size of bioengineered tooth germs. In vitro IGF-I signaling promotes cell proliferation, differentiation, and matrix secretion in mouse tooth germs, and so it can be hypothesized that IGF-I regulates tooth morphogenesis $[4,15]$.

Oyanagi et al. [15] showed that the combination of IGF-I and BMP2 promotes odontoblast differentiation and the expression of the ameloblastin enamel matrix gene (Ambn) in mice. Their research demonstrated that the expression of $A m b n$ is directly enhanced by IGF-I in dental epithelial cells, so Ambn may play an essential role in normal ameloblast differentiation. It is interesting that at least a hundred genes have been recognized as being expressed during different stages of amelogenesis; this total includes genes that codify sex hormone receptors and growth hormone receptors [16]. Estrogen plays an essential role during tooth formation by influencing the process of enamel and dentin mineralization. An animal model of estrogen deficiency showed a significant reduction in enamel microhardness [16]. The results reported by Arid et al. [16] in humans have demonstrated that genetic polymorphism in estrogen receptors (rs12154178) and in GH receptors (rs1509460) is associated with alterations in ameloblast function and developmental defects of enamel (DDE). It must be remembered that disturbances in enamel formation are associated with poor esthetics and the higher susceptibility of teeth to harmful local factors. Developmental enamel defects increase the risk of dental caries and noncarious tooth surface loss, which affect long-term dental health $[17,18]$. The posteruptive onset of the caries process takes part for as long as three years after permanent tooth eruption [19]. Caries in primary teeth shows a rapid course, due to the specific morphological structure and a lower degree of mineralization. Effective prevention and treatment, especially in the case of primary dentition, can considerably extend the time that a tooth remains in the oral cavity, thus preventing the consequences of its premature loss. In patients with growth hormone deficiencies, missing teeth and tooth-bone discrepancies become risk factors for masticatory organ disorders.

Isolated growth hormone deficiency (IGHD) may be caused by various genetic factors or by structural changes in the hypothalamus or pituitary, but the most commonly diagnosed form of the disease is idiopathic, with an unknown cause [20-23]. The main symptoms of IGHD include short stature and poor growth velocity [22,24,25]. Moreover, the length and depth of the face are generally inappropriately small for the child's age. Some studies have reported that mandibular total length is reduced, primarily as a result of small ramus height. In addition, the maxilla, although reduced and often retrognathic, is affected less than the mandible [2]. Disturbances such as agenesis and crown anomalies are also observed, aside from enamel and dentin malformation $[8,26]$. Children who received long-term GH therapy (for over two years) show increased growth of the craniofacial skeleton, and especially of the maxilla and mandibular ramus. These findings suggest that GH accelerates craniofacial development, which improves occlusion and facial profile [2].

Data from the literature confirm that dental age is delayed with respect to chronological age by up to two years in growth hormone-deficient (GHD) children [27]. It has been reported that tooth eruption, defined as the mucosal penetration of any visible part of a tooth into the oral cavity, is delayed in both primary and permanent dentition $[27,28]$. The relationship between the maturation of the skeletal system and the formation of permanent dentition has been confirmed in several studies $[29,30]$. There is a relationship between 
mineralization of the canine and the MP3 stage- one of the stages of ossification of the middle phalanx of the third finger in the development of bones of the wrist [29]. Moreover, the relationship between dental age and maturity in the cervical vertebrae is also determined. A significant association has been confirmed between cervical vertebral maturation (CMV) classification and the development of canine and second premolar teeth [31]. At the same time, it should be remembered that the time for emergence of permanent premolars and canines can be modified by the activity of caries in primary teeth. Several studies have concluded that early extraction of second primary molar or caries in primary molars can accelerate the clinical eruption of permanent second molars [32].

The study aimed to conduct a systematic review of knowledge of oral health relating to craniofacial development, occlusion, dental age, dental caries, enamel defects, and tooth wear in children with GHD.

\section{Materials and Methods}

\subsection{Inclusion and Exclusion Criteria}

The literature search was based on a previously prepared protocol that defined inclusion and exclusion criteria, a search strategy, and the data analysis [33]. The systematic review protocol was registered with PROSPERO, registration number: CRD42021250229 [34].

This systematic review of the available literature on the condition of the teeth of pediatric GHD patients in terms of dental caries, tooth wear, enamel defects, and dental maturity and tooth eruption, craniofacial growth and morphology, and malocclusion was carried out in accordance with Cochrane Collaboration guidelines [33].

Human clinical trials and observational studies related to dental caries, tooth wear, enamel defects, tooth eruption and dental maturity, malocclusion, and craniofacial growth and morphology in pediatric GHD patients were included. The exclusion criteria: (1) nonhuman studies and in vitro studies; (2) subjects with syndromic short stature, idiopathic short stature (ISS) or neoplasia; (3) case reports and reviews; (4) editorials, commentaries, books, and letters to editors; and (5) articles without available full text. The search strategy was based on the Preferred Reporting Items for Systematic Reviews and Meta-analyses (PRISMA) guidelines [35] (Figure 1).

\subsection{Search Strategy}

We searched Scopus (2000 to May 2021), MEDLINE-EbscoHost (2000 to May 2021), and Web of Science (2000 to May 2021). As the aim was to present the most recent summary of evidence, the analysis covered publications from the last 20 years, from January 2000 to May 2021, in English or Polish. The present systematic review has been designed to answer the question "Are children diagnosed with GHD, when compared to heathy or GH treated children, more often affected by oral health problems?" formulated according to PICO ("Population", "Intervention", "Comparison", "Outcome") [36]. The search strategy was carried out using MeSH (Medical Subject Headings) synonyms and Boolean logical operators. The following terms were used in search engines: "growth hormone deficiency" AND ("enamel" OR "tooth wear" OR "caries"); "growth hormone deficiency" AND "dental maturity"; "growth hormone deficiency" AND "craniofacial morphology"; "growth hormone deficiency" AND "craniofacial growth"; "growth hormone deficiency" AND "malocclusion". The first search was made on 5 January 2021 and the final one on 2 May 2021.

Studies were selected independently by two review authors (N.T.-W. and K.A.M.) Eligibility was determined by discussion where there were discrepancies. We searched manually for additional studies by cross-checking the reference lists of all the included studies. Duplicate publications were removed. Two of the review authors (N.T.-W. and K.A.M.) independently screened titles and abstracts of all the identified articles so that each record was checked twice. If a title and abstract met the inclusion criteria, the full texts of all potentially relevant articles were retrieved. Full-text articles were reviewed in detail and independently for eligibility criteria by two review authors. 


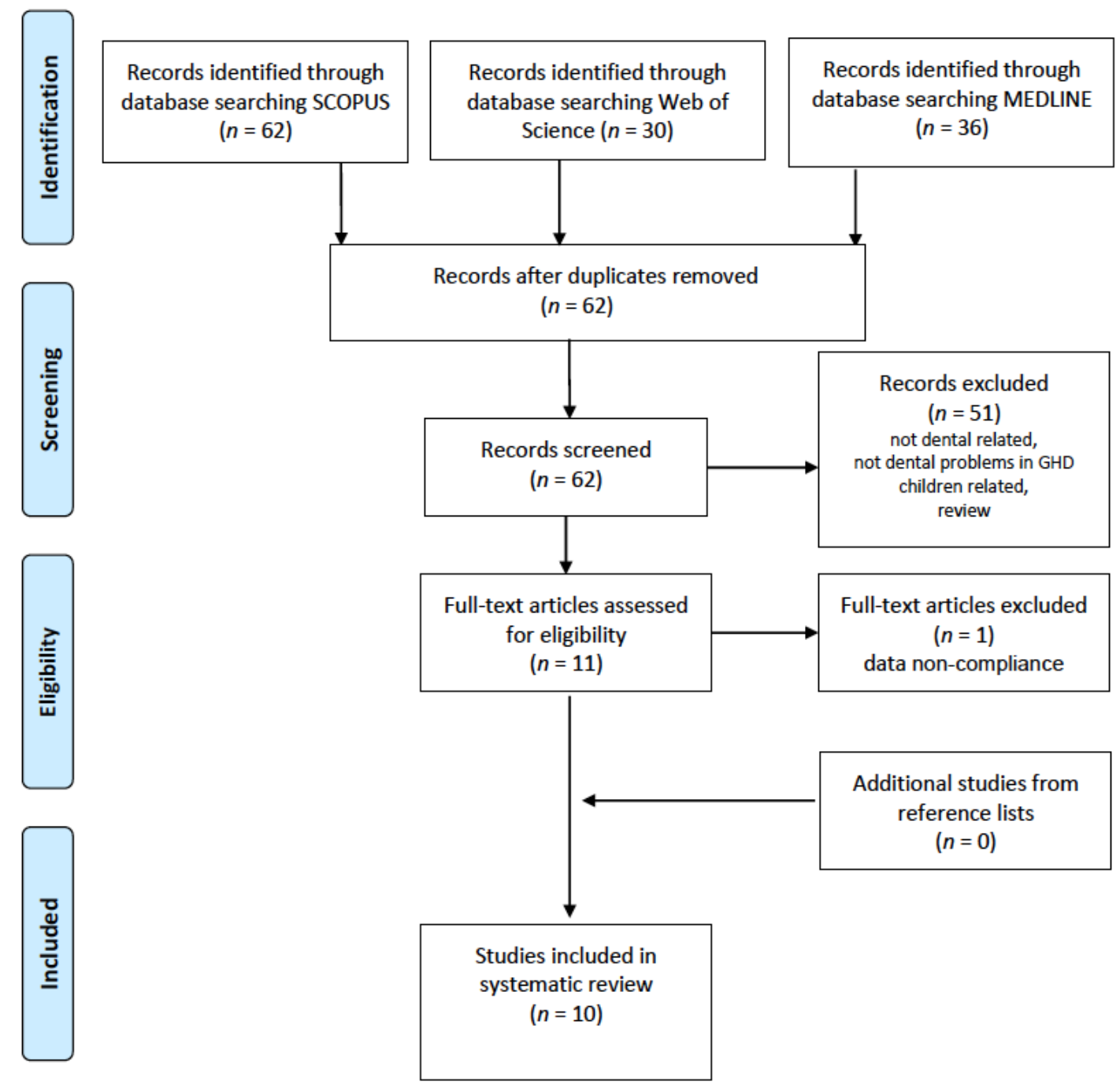

Figure 1. PRISMA flowchart of the study selection process.

\subsection{Data Extraction and Management}

Two review authors (N.T.-W. and K.A.M.) independently extracted all the relevant data from the eligible studies and recorded it on a specifically designed form. Any discrepancies were resolved by discussion. If no agreement could be reached, arbitration was carried out by a third review author (J.O.-S.) Data extraction included the following: name of authors, country of patients, year of publication, study group, control group, study design, prevalence of dental caries, tooth wear, tooth eruption and dental maturity, enamel defects, malocclusion, and craniofacial growth and morphology in pediatric GHD patients.

To evaluate the risk of bias, reviewers independently (N.T.-W., K.A.M) evaluated the methodological quality of the studies using the adopted version of Newcastle-Ottawa Quality Assessment Scale according to a star-based system [37,38]. Any discrepancies were resolved by the third author (J.O.-S.) Each study was judged on three categories: the selection of the study groups, the comparability of the study groups, and the ascertainment of the outcome. A study could be awarded a maximum of two stars for the comparability category, the ascertainment of the factor and the assessment of outcomes items and a maximum of one star for each other numbered item within the selection and outcome categories.

The following criteria of reliability were used: $\geq 7$ stars represented a low risk of bias (good quality study), 5-6 stars a medium risk of bias (fair quality study), and $\leq 4$ stars a high risk of bias (poor quality study). 


\section{Results}

After duplicates were manually eliminated, our systematic search of the three medical databases yielded a total of 62 publications meeting the search criteria. An initial selection of these was made using their titles and abstracts.

A total of fifty one articles were excluded because they focused on topics other than dental status, they did not study pediatric GHD patients, or they were reviews. Based on the full text, ten publications were qualified for further analysis; two of these concerned the mineralized tissues of the tooth-dental caries [39,40], two dealt with dental maturity $[28,41]$, two with malocclusion [28,42], and six with craniofacial growth or morphology. One paper was excluded because of inconsistent data [2,28,43-46] (Figure 1).

Two articles worked with the same group of patients $[39,40]$; for this reason, some results were considered only once.

The publications describe patients living in North America, Asia, and Europe [2,28,39-46] (Table 1). All the studies involved patients from 5 to 18 years of age, covering a total of 465 GHD and 51 ISS (idiopathic short stature) individuals. Patients with ISS, as described by Choi et al. [45], Hodge et al. [42] and Kim et al. [43], were not considered in our analysis. Two studies (by Segal et al. [46] and Hodge et al. [42]) provided no information on the sex of the patients. One study by Kjellberg et al. [28] dealt only with male patients. Except for the articles of Segal et al. [44], Hodge et al. [42], Choi et al. [45], and Kim et al. [43], the studies all described only GHD and untreated GHD patients. In Segal et al. [46], eleven patients had multiple pituitary hormone deficiencies. The control groups in the studies included healthy children [41,43,45] or relatives [46], reference materials [2,28,44], medical records [42], and study groups divided into subgroups [39,40,45,46]. In five articles the researchers were dentists or dental hygienists [28,39,40,43,45]. Two papers [39,40] included analysis of vitamin D levels. Other vitamin and mineral deficiencies were not assessed.

\subsection{Hard Mineralized Tissue Pathology}

Dental caries were examined in two publications presenting the same patient cohort $[39,40]$ (Table 2). The dental examinations were carried out in line with World Health Organization (WHO) criteria for epidemiological studies. The severity of dental caries was assessed using the DMFT index, which identifies those teeth $(\mathrm{T})$ which have cavities (D); are missing (M); or have been filled (F) as a result of caries. A statistically significant effect of vitamin D3 concentration on the DMFT index and its component DT was found among children from rural areas, where an increase in vitamin D3 concentration by ten units resulted in a decrease in the value of DMFT by 0.82 and a decrease in the value of DT component by 0.66 . The percentage of these children with active caries was higher than in urban areas, but not statistically significantly [39]. A positive and statistically significant correlation between the duration of GH therapy and DMFT index was, however, observed in patients from urban areas [40]. There was no healthy control group in this study. 
Table 1. Studies included in the systematic review.

\begin{tabular}{|c|c|c|c|c|c|}
\hline Reference & Country & $\begin{array}{l}\text { GHD Group } \\
\text { Patients and Age }\end{array}$ & $\begin{array}{l}\text { Control Group } \\
\text { Patients and Age }\end{array}$ & $\begin{array}{l}\text { Number/Qualification } \\
\text { of Examiner(s) }\end{array}$ & $\begin{array}{l}\text { Statistical } \\
\text { Methods }\end{array}$ \\
\hline Kjellberg et al. (2000) [28] & Sweden & $\begin{array}{c}48 \text { boys; } 20 \text { GHD } 12.1 \pm 1.7 \text { years, range } \\
9.1-14.8 ; \\
28 \text { non-GHD } 11.6 \pm 1.7 \text { years, range } \\
7.3-15.0\end{array}$ & $\begin{array}{l}\text { Reference materials; sagittal cephalograms }-109 \text { healthy } \\
\text { controls, } 12.0 \text { years; PA-cephalograms }-588 \text { Australian } \\
\text { schoolchildren } 6-15 \text { years; } 67 \text { boys, } 12-13 \text { years; } \\
\text { occlusion-686 boys, } 12 \text { years; dental maturity- } 453 \text { children; } \\
\text { Tooth eruption-122 randomly selected boys; } 2-18 \text { years }\end{array}$ & 2/dentist-unknown & $\begin{array}{l}\text { Unpaired } t \text {-test, paired } t \text {-test } \\
\text { Areas in two tails of the standard } \\
\text { normal curve } \\
\text { Statview v.4.5 }\end{array}$ \\
\hline Segal et al. (2004) [46] & USA & $\begin{array}{l}52 \text { GHD subjects: } \\
41 \text { isolated GHD, } \\
11 \text { multiple pituitary } \mathrm{HD} ; 12.8 \pm 4.3 \text { years }\end{array}$ & $\begin{array}{c}41 \text { healthy first-degree relatives; } \\
12 \text { untreated subjects with GHD, } 9.2 \pm 3.8 \text { years; } \\
2953 \text { healthy controls, } 0-18 \text { years } \\
\text { (literature reference data) }\end{array}$ & 1/unknown & $\begin{array}{l}\text { t-test; non-parametric tests; } \\
\text { post-hoc comparison } \\
\text { linear regression }\end{array}$ \\
\hline Hodge et al. (2015) [42] & USA & $\begin{array}{c}\text { 16; } 12 \mathrm{GHD}, \\
\text { 3 IGFD + } 1 \text { ISS; } \\
12.9 \text { years, } \\
\text { range } 5-14.11 \text { years }\end{array}$ & $\begin{array}{l}\text { The sample of the U.S. population examined during the } \\
\text { National Health and Nutrition Survey } \\
\text { (NHANES) (medial records) }\end{array}$ & Unknown & $t$-test \\
\hline Choi et al. (2017) [45] & South Korea & $\begin{array}{c}36 ; 10 \text { boys and } 8 \text { girls in both group; } \\
18 \mathrm{GHD} \\
18 \mathrm{ISS}, 11.3 \pm 1.8 \text { years }\end{array}$ & $\begin{array}{c}\text { The same } 18 \text { GHD } 11.3 \pm 1.8 \text { years; } \\
\text { Data of } 18 \text { healthy children selected from elementary } \\
\text { schools in Daegu-data selected to fit short stature children }\end{array}$ & $1 /$ dentist & $\begin{array}{c}\text { Shapiro-Wilk test, Kruskal-Wallis test, } \\
\text { Mann-Witney U test, Spearman's rank } \\
\text { correlation coefficients } \\
\text { IBM SPSS } 21.0\end{array}$ \\
\hline $\begin{array}{l}\text { Wójcik et al. (2018) [39] } \\
\text { Wójcik et al. (2019) [40] }\end{array}$ & Poland & $\begin{array}{l}121 ; 92 \text { boys, } 29 \text { girls; } ; 3.73 \pm 2.40 \text { years, } \\
\text { range } 6-18 \text { years }\end{array}$ & $\begin{array}{l}\text { The study group divided by residence into } 2 \text { comparative } \\
\text { groups- from urban and rural areas: } \\
56 \text { rural areas } \\
65 \text { urban areas }\end{array}$ & unknown/dentist & $\begin{array}{l}\text { Kruskal-Wallis test, Mann-Witney U test, } \\
\text { Spearman's rank correlation coefficients; } \\
\text { t-test; Pearson's linear correlation coefficient; } \\
\text { Pearson's Chi2 test } \\
\text { Statistica } 10 \text { software package }\end{array}$ \\
\hline Partyka et al. (2018) [41] & Poland & $\begin{array}{c}110 ; 27 \text { males, } 83 \text { females; } \\
13 \pm 2.6 \text { years }\end{array}$ & $\begin{array}{c}41 \text { generally healthy children hospitalized in the } \\
\text { Department of Pediatric Otolaryngology; } \\
15 \text { males, } \\
25 \text { females; } 11.5 \pm 2.5 \text { years }\end{array}$ & unknown & Statistica 10 software package \\
\hline Preda et al. (2019) [44] & Romania & $\begin{array}{l}13 \text { isolated GH deficient; } \\
9 \text { boys, } 4 \text { girls; } \\
\text { range } 9-13 \text { years }\end{array}$ & $\begin{array}{l}\text { Data from the literature } \\
\text { regarding the age of the subjects and the pathology }\end{array}$ & 1/unknown & $\begin{array}{c}\text { Shapiro-Wilk and } \\
\text { Anderson-Darling tests; } \\
t \text {-test; analysis of variance (ANOVA) } \\
\text { Statistical Package for Social Sciences (SPSS) } \\
\end{array}$ \\
\hline Kim et al. (2021) [43] & Korea & $\begin{array}{c}\text { 63; } 31 \text { growth hormone deficient (SS-HD); } \\
16 \text { male, } 15 \text { female; } 10.35 \pm 1.84 \text { years; } 32 \\
\text { idiopatic short stature (SS-I) } \\
10.31 \pm 1.82 \text { years }\end{array}$ & $\begin{array}{l}32 \mathrm{NC} \text { (normal children), } 17 \text { males and } 15 \text { females, who } \\
\text { had visited the dental clinic in Daegu, } 10.31 \pm 1.82 \text { years }\end{array}$ & $2 /$ dentist and hygienist & $\begin{array}{c}\text { Multivariate analysis } \\
\text { of variance (ANOVA) } \\
\text { IBM Statistical Package for Social } \\
\text { Sciences (SPSS) }\end{array}$ \\
\hline
\end{tabular}


Table 2. Dental caries experience-data abstracted from studies included in systematic review.

\begin{tabular}{|c|c|c|c|}
\hline Reference & GHD Patients Rural Areas & $\begin{array}{c}\text { Control Group-GHD Patients } \\
\text { Urban Areas }\end{array}$ & Conclusions \\
\hline $\begin{array}{l}\text { Wójcik et al. (2018) [39] } \\
\text { Wójcik et al. (2019) [40] }\end{array}$ & $\begin{array}{c}\text { DMFT }=4.36 \pm 2.98 \text { rural } \\
\text { DMFT from } 0 \text { to } 12 \\
\text { Vitamin D3 concentration lower } \\
\text { than } 10 \mathrm{ng} / \mathrm{mL} \\
\text { DMFT }=7.67 \pm 2.08 \\
\text { DT }=4.67 \pm 3.73 \\
\text { Vitamin } \mathrm{D} 3 \text { concentration lower } \\
\text { than } 20 \mathrm{ng} / \mathrm{mL} \\
\text { DMFT }=5.55 \pm 2.56 \\
\text { DT }=3.78 \pm 2.68 \\
\text { Vitamin } \mathrm{D} 3 \text { concentration lower } \\
\text { than } 30 \mathrm{ng} / \mathrm{mL} \\
\text { DMFT }=4.08 \pm 2.26 \\
\text { DT }=1.38 \pm 1.27 \\
\text { than } 30 \mathrm{ng} / \mathrm{mL} \\
\text { Vitamin } \mathrm{D} \text { concentration higher } \\
\text { DMFT }=3.70 \pm 3.05 \\
\text { DT }=1.93 \pm 1.66 \\
\text { Increase in vitamin } \mathrm{D} 3 \\
\text { concentration by } 10 \text { units decrease } \\
\text { in the value of DMFT by } 0.82, \text { of } \\
\text { DT component by } 0.66 .\end{array}$ & $\begin{array}{c}\text { DMFT }=3.82 \pm 3.76 \text { urban } \\
\text { DMFT from } 0 \text { to } 16 \\
\text { Vitamin D3 concentration lower } \\
\text { than } 10 \mathrm{ng} / \mathrm{mL} \\
\text { DMFT }=1.00 \pm 0.33 \\
\text { DT }=0.50 \pm 0.71 \\
\text { Vitamin D3 concentration lower } \\
\text { than } 20 \mathrm{ng} / \mathrm{mL} \\
\text { DMFT }=4.25 \pm 3.35 \\
\text { DT }=1.31 \pm 1.94 \\
\text { Vitamin D3 concentration lower } \\
\text { than } 30 \mathrm{ng} / \mathrm{mL} \\
\text { DMFT }=3.93 \pm 1.96 \\
\text { DT }=1.85 \pm 2.07 \\
\text { Vitamin D3 concentration higher } \\
\text { than } 30 \mathrm{ng} / \mathrm{mL} \\
\text { DMFT }=2.95 \pm 2.21 \\
\text { DT }=0.79 \pm 0.88\end{array}$ & $\begin{array}{l}\text { The percentage of rural patients } \\
\text { with active caries is higher than } \\
\text { of urban patients, but not } \\
\text { significantly different }(p=0.11) \text {. } \\
\text { No significant impact of vitamin } \\
\text { D3 concentration on DMFT in } \\
\text { urban areas. } \\
\text { The statistically significant } \\
\text { impact of vitamin D3 } \\
\text { concentration on DMFT } \\
\text { in rural areas } \\
(p<0.05) \text {. } \\
\text { Significant impact of vitamin D3 } \\
\text { concentration on the value of DT } \\
\text { component }(p=0.023) \text {. }\end{array}$ \\
\hline Wójcik et al. (2019) [40] & $\begin{array}{l}\text { DMFT index vs. duration of GH } \\
\text { therapy-no correlation }\end{array}$ & $\begin{array}{c}\text { DMFT index vs. duration of GH } \\
\text { therapy-formula: } \\
\text { DMFT }=1.49+0.07^{*} \text { duration } \\
\text { of therapy }\end{array}$ & $\begin{array}{c}\text { The statistical significant } \\
\text { correlation between the duration } \\
\text { of the GH therapy and the DMFT } \\
\text { index among patients from urban } \\
\text { areas (test for Pearson's } \\
\text { correlation coefficient } r=0.33, \\
t=2.79 ; p=0.007 \text { ) } \\
\text { No statistically significant } \\
\text { correlation between the duration } \\
\text { of the GH therapy and the DMFT } \\
\text { index among patients from rural } \\
\text { areas (test for Pearson's } \\
\text { correlation coefficient } r=0.11, \\
t=0.87 ; p=0.38 \text { ) }\end{array}$ \\
\hline
\end{tabular}

\subsection{Dental Maturity and Malocclusion}

Two of the papers we considered describe the prevalence of malocclusion in GHD children [28,42] (Table 3). Both used the relations of first permanent molars (Angle's classification) to detect deviations from Angle's Class I occlusion, where the mesiobuccal cusp of maxillary first molar occludes in the buccal groove of the mandibular first molar. In the study of Kjellberg et al. [28], 29\% of the boys in the study group showed Angle's Class II malocclusion, while the remainder were Angle's Class I. Dental crowding of at least $2 \mathrm{~mm}$ was recorded in $44 \%$ of patients. A large overjet $(>6 \mathrm{~mm}$ ) was seen in $14 \%$, and a large overbite $(>5 \mathrm{~mm})$ in $5 \%$.

Hodge et al. [42] observed Angle's Class II in 31\% and Angle's Class III in 6\% of patients. Increased overjet and deep overbite were each found in up to $37 \%$ of subjects, which is a significantly greater prevalence than in Kjellberg et al. [28] However, these discrepancies are probably due to differences in methodology and definitions. In the study of Hodge et al. [42], an overjet greater than $2 \mathrm{~mm}$ and an overbite greater than $3 \mathrm{~mm}$ were considered abnormal, while Kjellberg et al. [28] noted only more extreme abnormalities. Unlike Hodge et al. [42], Kjellberg et al. [28] used radiographs and plaster models to record relations between the jaws. 
Table 3. Malocclusion and dental maturity—data abstracted from studies included in the systematic review.

\begin{tabular}{|c|c|c|c|c|}
\hline Reference & Methods of Study & GHD Patients & Control Group & Conclusions \\
\hline $\begin{array}{l}\text { Kjellberg et al. } \\
(2000) \text { [28] }\end{array}$ & $\begin{array}{l}\text { Malocclusion } \\
\text { recorded on plaster model } \\
\text { Angle's Class II defined as } \\
\text { cusp to cusp relation or } \\
\text { full Class II relation } \\
\text { Increased OJ } \geq 6 \mathrm{~mm} \\
\text { Increased OB } \geq 5 \mathrm{~mm}\end{array}$ & $\begin{array}{c}\text { Class II } \\
\text { GHD 22.2\% } \\
\text { Non-GHD 25.9\% } \\
\text { GHD+ non-GHD } \\
29 \% \text { Class II } \\
71 \% \text { Class I } \\
\text { OJ } 14 \% \\
\text { OB } 5 \%\end{array}$ & $\begin{array}{c}26.7 \% \text { Class II } \\
\text { OJ }<2 \mathrm{~mm} \\
\mathrm{OB}<3 \mathrm{~mm}\end{array}$ & None \\
\hline $\begin{array}{l}\text { Hodge et al. } \\
\text { (2015) [42] }\end{array}$ & $\begin{array}{c}\text { Malocclusion } \\
\text { Angle's Class I, II, III } \\
\text { classification } \\
\text { Increased OJ }>2 \mathrm{~mm} \\
\text { Increased OB }>3 \mathrm{~mm}\end{array}$ & $\begin{array}{l}31 \% \text { Class II } \\
6 \% \text { Class III } \\
\text { OJ } 37 \% \\
\text { OB } 37 \%\end{array}$ & $\begin{array}{c}\text { Class II } \\
35 \% \\
6-11-\text { year-olds } \\
32 \% \\
12-17-\text { year-olds }\end{array}$ & None \\
\hline $\begin{array}{l}\text { Kjellberg et al. } \\
\text { (2000) [28] }\end{array}$ & $\begin{array}{c}\text { Dental Maturity } \\
\text { Measured as tooth } \\
\text { formation, Demirjian } \\
\text { method }\end{array}$ & $\begin{array}{c}\text { Dental maturity } \\
\text { GHD } 11.1 \pm 1.7 \text { years } \\
\text { Non-GHD } 10.2 \pm 1.8 \text { years } \\
\text { Difference Dental age/Birth age } \\
\text { GHD Difference }-1.0 \\
\text { Non-GHD Difference }-1.3 \\
\text { GHD + non-GHD } \\
-1.2 \text { years }\end{array}$ & $\begin{array}{l}\text { No detailed data, } \\
\text { A Finnish sample of } \\
\text { 12-year-olds }\end{array}$ & $\begin{array}{l}\text { Statistical significant } \\
\text { differences in birth age vs. } \\
\text { dental age between patients } \\
\text { and control group } \\
\quad(p<0.001)\end{array}$ \\
\hline $\begin{array}{l}\text { Partyka et al. } \\
\text { (2018) [41] }\end{array}$ & $\begin{array}{l}\text { Dental Maturity } \\
\text { Matiegka and } \\
\text { Lukasova method }\end{array}$ & $\begin{array}{c}\text { Dental maturity } \\
\text { The group starting treatment } \\
138.97 \pm 27.76 \text { months } \\
\text { The group in the course of } \\
\text { treatment } 153.23 \pm \\
25.72 \text { months } \\
\text { Difference Dental age/Birth age } \\
\text { All patients } \\
-9.70 \pm 16.37 \text { months } \\
\text { The group starting treatment } \\
-18.82 \pm 18.28 \text { months } \\
\text { The group in the course of } \\
\text { treatment }-2.70 \pm \\
10.40 \text { months }\end{array}$ & $\begin{array}{c}\text { Dental maturity } \\
141 \pm 40 \text { months } \\
\text { Difference Dental age/Birth age } \\
+3.98 \pm 11.06 \text { months }\end{array}$ & $\begin{array}{l}\text { Dental age (maturity) of GHD } \\
\text { patients is significantly } \\
\text { delayed ( } p=0.000) \\
\text { Statistical significant } \\
\text { differences between birth age } \\
\text { and dental age in patients } \\
\text { starting treatment }(p=0.005)\end{array}$ \\
\hline
\end{tabular}

Dental maturity was evaluated in two studies by Kjellberg et al. [28] and Partyka et al. [41] Each investigator used a different method: the method of Demirjian was employed by Kjellberg and the method of Matiegka and Lukasova by Partyka; both of which were validated. Kjellberg et al. [28] defined dental maturity on the basis of tooth formation recorded on orthopantomograms. The sum of scores for each individual was converted into a dental age in accordance with the instructions given by Demirjian. The method of Matiegka and Lukasova established dental age by identifying the most recently erupted full group of teeth, including incomplete groups. From Matiegka's table for boys and Lukasova's for girls, age corresponding with the number of teeth can be found, giving a result for a specific patient [41]. Both studies showed statistically significant differences between birth age and dental age between the GHD and non-GHD patients and control groups [28], and between birth age and dental age in patients starting treatment [41]. In Kjellberg et al. [28], dental maturity was delayed about one year in both the non-GHD and GHD boys. Partyka et al. [41] reported a delay of 18.82 and 2.70 months (for the group starting treatment and that undergoing treatment, respectively).

\subsection{Craniofacial Growth/Morphology}

Six articles on craniofacial growth and morphology were included in the systematic review [2,28,43-46] (Table 4). Five publications used lateral cephalograms to measure the results $[2,28,43-45]$. The number of landmarks and the linear and angular measurements differ between the studies, and three articles mentioned the methods used: Kjellberg et al. [28] used the Bjork method, Choi et al. [45] used Pancherz's method, and Segal et al. [46] used the triangulation methods developed by Bookstein. Anterior cranial base length was found to be significantly reduced by Preda et al. [44], Kim et al. [43], and Choi et al. [45], while the posterior cranial base length was shorter in Kjellberg et al. [28], Preda et al. [44], Choi et al. [45], and Kim et al. [43] Total cranial base length was significantly less in Preda et al. [44] and Kim et al. [43] Lower anterior facial height was significantly smaller 
among boys and girls prior to and during treatment in Funatsu et al. [2] Segal et al. [46] also found smaller vertical proportions, suggesting a deficiency in the lower face. Both mandibular ramus height and corpus length were shorter in boys prior to treatment in Choi et al. [45] Smaller mandibular corpus lengths were noted by Preda et al. [44] among boys and girls, and prior to and during treatment in Funatsu et al. [2], while mandibular ramus lengths were shorted in untreated boys in Kim et al. [43] The measured angles referred to the mandible's and maxilla's retroposition $[28,43,44]$. Significant differences between the studied group were also apparent in the angle between the maxillary and mandibular planes, which was larger than normal [43-45].

Table 4. Anthropometric craniofacial characteristics—-data abstracted from studies included in systematic review.

\begin{tabular}{|c|c|c|c|c|}
\hline Reference & Methods of Study & $\begin{array}{c}\text { Linear } \\
\text { Measurements } \\
\text { GHD Patients }\end{array}$ & $\begin{array}{c}\text { Angular } \\
\text { Measurements }\end{array}$ & Conclusions \\
\hline $\begin{array}{l}\text { Kjellberg et al. } \\
\text { (2000) [28] }\end{array}$ & $\begin{array}{l}\text { Lateral cephalograms, } \\
\text { Bjork method } \\
10 \text { Linear and } 12 \text { angular } \\
\text { measurements, } \\
2 \text { ratios. }\end{array}$ & $\begin{array}{l}\text { s-n }(\mathrm{mm}) \\
\text { s-ba }(\mathrm{mm}) \\
\text { n-sp' }(\mathrm{mm}) \\
\text { sp-pm }(\mathrm{mm}) \\
\text { sp'-gn }(\mathrm{mm}) \\
\text { tgo-ar }(\mathrm{mm}) \\
\text { gn-tgo }(\mathrm{mm}) \\
\text { ar-gn }(\mathrm{mm}) \\
\text { n-gn }(\mathrm{mm}) \\
\text { tgo'-tgo }(\mathrm{mm})\end{array}$ & $\begin{array}{l}\text { Cranial } \\
\text { n-s-ba } \\
\text { n-s-ar } \\
\text { Facial } \\
\text { upper/lower } \\
\text { s-n-ss } \\
\text { NL/NSL } \\
\text { s-n-sm } \\
\text { s-n-pg } \\
\text { ML/NSL } \\
\text { ML/NL } \\
\text { gn-tgo-ar } \\
\text { ss-n-sm } \\
\text { s-ar-tgo } \\
\text { n-ss-pg }\end{array}$ & $\begin{array}{c}\text { No significant differences were detected between the } \\
28 \text { non-GHD and } 20 \text { GHD patients. } \\
\text { All linear measurements, except s-n and gn-tgo, were } \\
\text { significantly smaller in } \\
\text { the study group. } \\
\text { A flat medial and lateral cranial base angle } \\
(p=0.002) \text { and large gonion angle }(p=0.002) \\
\text { were significant characteristics of studied patients. } \\
\text { Both the mandible }(p<0.000) \text { and maxilla }(p=0.004) \text { were } \\
\text { significantly } \\
\text { retropositioned. } \\
\text { The mandible showed an increase in } \\
\text { the vertical inclination }(p<0.000) \text {. }\end{array}$ \\
\hline $\begin{array}{l}\text { Segal et al. } \\
(2004)[46]\end{array}$ & $\begin{array}{c}\text { Triangulation methods } \\
\text { developed } \\
\text { by Bookstein, } \\
22 \text { landmark points }\end{array}$ & & & $\begin{array}{c}\text { The vertical proportions of untreated } \\
\text { patients were significantly smaller in comparison with } \\
\text { normal relatives } p<0.001 \text {; } \\
\text { Deficit in facial proportions localized in the lower face. } \\
\text { The vertical proportions of treated } \\
\text { patients were not significantly smaller. }\end{array}$ \\
\hline $\begin{array}{l}\text { Funatsu et al. } \\
\text { (2006) [2] }\end{array}$ & $\begin{array}{l}\text { Two cephalometric } \\
\text { radiographs- in centric } \\
\text { occlusion and wide } \\
\text { opening lateral; } \\
12 \text { lendmarks; } \\
8 \text { Linear and } 5 \text { angular } \\
\text { measurements. }\end{array}$ & $\begin{array}{c}\text { N-S, mm } \\
\text { N-Me, mm } \\
\text { N-ANS, mm } \\
\text { ANS-Me, mm } \\
\text { A-Ptm, mm } \\
\text { Gn-Cd, mm } \\
\text { Pog-Go, mm } \\
\text { Cd-Go, mm }\end{array}$ & $\begin{array}{l}\angle \mathrm{SNA}, \\
\angle \mathrm{SNB}, \\
\angle \mathrm{ANB}, \\
\text { Mandibular } \\
\text { plane to SN, } \\
\text { Gonial angle }\end{array}$ & $\begin{array}{c}\text { Ans-Me, }<\text { Gn-Cd,A'-Ptm',Pog'-Go, } \\
\text { Cd-Go were significantly smaller in boys and } \\
\text { ANS-Me,Gn-Cd, Pog'-Go } \\
\text { in girls in } \\
\text { untreated group. } \\
\text { Cg-Go was significantly larger; SNA, } \\
\text { gonial angle were significantly smaller in boys; gonial } \\
\text { angle in girls in short-term therapy. } \\
\text { N-Me', ANS-Me, A'-Ptm', Pog'-Go, } \\
\text { Cd-Go, gonial angle were significantly smaller in boys } \\
\text { and ANS-Me, } \\
\text { Cd-Go, gonial angle were significantly smaller but } \\
\text { A'-Ptm' was significantly larger in girls } \\
\text { in the long-term. } \\
\text { There was a significant difference } \\
\text { between the untreated and long-term therapy } \\
\text { in upper facial height, maxillary length and ramus } \\
\text { high-scores increased with } \\
\text { the duration of GH therapy }\end{array}$ \\
\hline $\begin{array}{l}\text { Choi et al. } \\
\text { (2017) [45] }\end{array}$ & $\begin{array}{l}\text { Lateral cephalograms at } \\
\text { T0 before } \\
\text { the treatment, } \\
\text { T1 } 2 \text { years after treatment, } \\
\text { Pancherz's method; } \\
9 \text { linear and } 7 \text { angular } \\
\text { measurements }\end{array}$ & $\begin{array}{c}\text { N-S } \\
\text { S-Ba } \\
\text { ANS-PNS } \\
\text { Ar-Go } \\
\text { Go-Gn } \\
\text { Ar-Gn } \\
\text { ANS-Me } \\
\text { N-Me } \\
\text { S-Go }\end{array}$ & $\begin{array}{l}\text { Cranial base } \\
\text { angle } \\
\text { (N-S-Ar) } \\
\text { Ramal angle } \\
\text { (SN-ArGo) } \\
\text { Gonial angle } \\
\text { (Ar-Go-Me) } \\
\text { SN-Go-Me } \\
\text { SNA, } \\
\text { SNB, } \\
\text { ANB }\end{array}$ & $\begin{array}{l}\text { Before treatment, boys had shorter N-S, } p=0.002 ; \mathrm{S}-\mathrm{Ba}, p \\
=0.004 ; \text { Ar-Go, } p=0.012 ; \mathrm{Go}-\mathrm{Gn}, p=0.008 \text { and greater } \\
\text { ANB, } p=0.018 . \\
\text { Girls had shorter N-S, } p=0.001 ; \\
\text { Ar-Go, } p=0.010 \text {. } \\
\text { Boys with GHD before treatment had } \\
\text { skeletal Class II tendency. } \\
\text { After treatment the sagittal skeletal } \\
\text { relationship improved significantly in boys with GHD } \\
\text { and ISS }\end{array}$ \\
\hline
\end{tabular}


Table 4. Cont.

\begin{tabular}{|c|c|c|c|c|}
\hline Reference & Methods of Study & $\begin{array}{c}\text { Linear } \\
\text { Measurements } \\
\text { GHD Patients }\end{array}$ & $\begin{array}{c}\text { Angular } \\
\text { Measurements }\end{array}$ & Conclusions \\
\hline $\begin{array}{l}\text { Preda et al. } \\
(2019) \text { [44] }\end{array}$ & $\begin{array}{c}\text { Lateral cephalograms, } \\
11 \text { linear and } 6 \text { angular } \\
\text { measurements }\end{array}$ & $\begin{array}{l}\text { n-s } \\
\text { s-ba } \\
\text { n-ba } \\
\text { n-sp } \\
\text { pm-sp } \\
\text { sp-gn } \\
\text { gn-go } \\
\text { ss-pm } \\
\text { ss-ba } \\
\text { s-pm } \\
\text { pm-ba }\end{array}$ & $\begin{array}{c}\text { SNA, } \\
\text { SNB, } \\
\text { ANB, } \\
\text { ML-NL } \\
\text { s-n-sm } \\
\text { s-n-ss }\end{array}$ & $\begin{array}{c}\text { SNA, SNB were significantly smaller }(p<0.001), \text { ANB was } \\
\text { higher }(p<0.001) \text {. S-n-ss and s-n-sm were } \\
\text { significantly lower }(p<0.001) . \\
\text { Linear measurements -N-s }(p=0047) \\
\text { sp-gn }(p=0.008) \text {, gn-go }(p=0.003), \\
\text { s-ba }(p<0.001), \text { n-ba }(p<0.001) \text { were } \\
\text { significantly reduced. }\end{array}$ \\
\hline $\begin{array}{l}\text { Kim et al. } \\
(2021) \text { [43] }\end{array}$ & $\begin{array}{c}\text { Lateral cephalograms, } \\
12 \text { landmarks, } \\
12 \text { linear and } 7 \text { angular } \\
\text { measurements }\end{array}$ & $\begin{array}{c}\text { N-S } \\
\text { S-BA } \\
\text { N-BA } \\
\text { N-ANS } \\
\text { S-PNS } \\
\text { ANS-Me } \\
\text { N-Me } \\
\text { S-go } \\
\text { ANS-PNS } \\
\text { Art-Go } \\
\text { Go-Pog } \\
\text { Art-Pog }\end{array}$ & $\begin{array}{l}\text { N-S-Art. } \\
\text { Art.-Go-Me } \\
\text { N-S-Go-Gn } \\
\text { SNA, } \\
\text { SNB, } \\
\text { ANB, } \\
\text { S-N-Art-Go }\end{array}$ & $\begin{array}{l}\text { Significant differences were at anterior, posterior, total } \\
\text { cranial base length } \\
\text { (N-S, s-ba, n-ba); upper posterior and posterior total facial } \\
\text { heigh (S-PNS, S-go), mandibular ramus height and } \\
\text { mandibular corpus length (Art-Go,Go-Pog) } \\
(p<0.05) \text {. } \\
\text { Significant differences were at saddle angle, gonial angle, } \\
\text { mandibular plane angle, position of maxilla, SNB } \\
\text { and ANB } \\
(p<0.05) .\end{array}$ \\
\hline
\end{tabular}

\subsection{Quality Assessment and Risk of Bias}

All studies were classified in accordance with the Cochrane collaboration guidelines [33]. A control group was used in all publications, although its size and structure was not always consistent. While only three groups were gender-paired $[2,28,45]$, most of them were similar to the study group in terms of age [2,28,39,40,42-44].

The control group in the study by Kjellberg et al. [28], Segal et al. [46], Hodge et al. [42], and Preda et al. [44] consisted of children from previous studies. None of the publications described the blindness of examiners. Intrarater and interrater reliability were calculated in Kjellberg et al. [28] and Choi et al. [45] All papers performed statistical analysis, although not all aspects were statistically analyzed in one of the studies [28].

The publications on malocclusion $[28,29]$ were found to be at medium risk of bias. Two articles on dental caries describe the same cohort of children and present similar conclusions $[39,40]$. One of them was classified as a good quality study, since it additionally included a sample size calculation [40]. One publication on craniofacial characteristics [44] was at medium risk, and five $[2,28,43,45,46]$ were at low risk. One publication on dental maturity [41] was at medium, one at low risk [28] (Table 5). 
Table 5. Quality assessment of studies using the Newcastle-Ottawa Scale ( $¥$ star (point) awarded in the quality assessment).

\begin{tabular}{|c|c|c|c|c|c|c|c|c|c|c|}
\hline \multirow[b]{2}{*}{ Reference } & \multirow[b]{2}{*}{ Problem } & \multicolumn{4}{|c|}{ Selection of the Study Groups } & \multirow{2}{*}{ Comparability } & \multicolumn{2}{|c|}{ Outcomes } & \multirow{2}{*}{$\begin{array}{l}\text { Appraisal } \\
\text { Score }\end{array}$} & \multirow{2}{*}{$\begin{array}{c}\text { Quality } \\
\text { Category } \\
\text { (Risk of Bias) }\end{array}$} \\
\hline & & $\begin{array}{l}\text { Representativeness } \\
\text { of Exposed Cohort }\end{array}$ & $\begin{array}{l}\text { Sample Size } \\
\text { Calculation }\end{array}$ & $\begin{array}{c}\text { Non- } \\
\text { Respondents }\end{array}$ & $\begin{array}{c}\text { Ascertainment } \\
\text { of the Factor }\end{array}$ & & $\begin{array}{c}\text { Assessment } \\
\text { of Outcomes }\end{array}$ & $\begin{array}{l}\text { Statistical } \\
\text { Tests }\end{array}$ & & \\
\hline \multirow{2}{*}{$\begin{array}{l}\text { Kjellberg et al. } \\
\text { (2000) [28] }\end{array}$} & malocclusion & $\star$ & - & - & 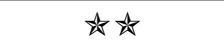 & $\star x$ & » & - & $6 / 10$ & Fair (medium) \\
\hline & $\begin{array}{c}\text { craniofacial } \\
\text { characteristics }\end{array}$ & $\star$ & - & - & t心 & $\star \star x$ & $\star \star x$ & $\star$ & $8 / 10$ & Good (low) \\
\hline $\begin{array}{l}\text { Segal et al. } \\
\text { (2004) [46] }\end{array}$ & $\begin{array}{c}\text { craniofacial } \\
\text { characteristics }\end{array}$ & $\star$ & - & $\star$ & $* t$ & $\star$ & $\star \star *$ & $\star x$ & $8 / 10$ & Good (low) \\
\hline $\begin{array}{l}\text { Funatsu et al. } \\
\text { (2006) [2] }\end{array}$ & $\begin{array}{c}\text { craniofacial } \\
\text { characteristics }\end{array}$ & $\star$ & - & - & $\star \star *$ & 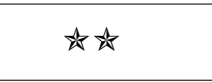 & $\star \star x$ & $\star$ & $8 / 10$ & Good (low) \\
\hline $\begin{array}{l}\text { Hodge et al. } \\
\text { (2015) [42] }\end{array}$ & malocclusion & $\star$ & - & - & $\star$ & - & $\star \star *$ & $\star$ & $5 / 10$ & Fair (medium) \\
\hline $\begin{array}{l}\text { Choi et al. } \\
(2017) \text { [45] }\end{array}$ & $\begin{array}{c}\text { craniofacial } \\
\text { characteristics }\end{array}$ & $\star$ & - & $\star$ & 如始 & $\star$ & $\star \star x$ & $\star$ & $8 / 10$ & Good (low) \\
\hline $\begin{array}{l}\text { Wójcik et al. } \\
\text { (2018) [39] }\end{array}$ & caries & $\star x$ & - & - & 办办 & - & *t心 & $\star \star$ & $6 / 10$ & Fair (medium) \\
\hline $\begin{array}{l}\text { Wójcik et al. } \\
\text { (2019) [40] }\end{array}$ & caries & $\star$ & $\star$ & & 加始 & - & 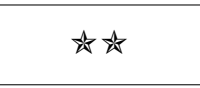 & $\star$ & $7 / 10$ & Good (low) \\
\hline $\begin{array}{l}\text { Partyka et al. } \\
\text { (2018) [41] }\end{array}$ & $\begin{array}{c}\text { dental } \\
\text { maturity }\end{array}$ & $\star$ & - & - & t心 & * & $\star * t$ & $\star$ & $7 / 10$ & Good (low) \\
\hline $\begin{array}{l}\text { Preda et al. } \\
\text { (2019) [44] }\end{array}$ & $\begin{array}{c}\text { craniofacial } \\
\text { characteristics }\end{array}$ & $\star$ & - & - & $\star *$ & - & $\star *$ & $\star$ & $6 / 10$ & Fair (medium) \\
\hline $\begin{array}{l}\text { Kim et al. } \\
(2020)[43]\end{array}$ & $\begin{array}{c}\text { craniofacial } \\
\text { characteristics }\end{array}$ & $\star$ & - & - & $\star *$ & $\star$ & $\star * t$ & $\star$ & $7 / 10$ & Good (low) \\
\hline
\end{tabular}




\section{Discussion}

Through their influence on bone metabolism, GH and IGF-I are major regulators of postnatal growth and development. GH acts directly on tissues by means of GH receptors, or indirectly by the production of insulin-like growth factor I. Metabolic agents and the growth hormone/insulin-like growth factor-I axis have a strong influence on the metabolism of oral tissues, particularly during the period of growth [8].

There is very little in the literature on oral cavity status in patients with GHD. Our systematic review has shown that some dental topics have not yet been discussed. There has been little to evaluate dental conditions like tooth wear and enamel defects, although we can assume that the effect of growth hormone on the dentition and facial bones is complex $[3,8]$. Publications on dental status and craniofacial growth in children with GHD are somewhat confined, and their results are not always concordant [6].

Some researchers have suggested a relationship between tooth wear and craniofacial morphology, as well as a correlation between tooth wear and malocclusion $[47,48]$. Tooth wear is defined as the mechanical or chemical removal of dental hard tissues, resulting in reduced tooth structure. The prevalence and severity of tooth wear in contemporary populations is on the increase, particularly in younger patients [49]. Patients with significant tooth wear have been described as having a characteristic craniofacial morphology. Cephalometric analysis has reported a reduction in lower anterior facial height, a more horizontal mandibular plane angle, a more acute gonial angle, and a greater posterior facial height [47]. It would be useful to examine these features in GHD children.

The size, growth, and osseous maturity of the jaw also play a role in the process of tooth eruption. A strong correlation has been shown between eruption time and dental maturity. The teeth typically erupt when they have reached a 2/3 root length [50], but individual correlation between chronological age and eruption time is inconsistent $[50,51]$. Research has demonstrated that, in GHD patients, dental age (maturity) is significantly delayed [28,41]. This is consistent with the results of Cantu et al. [27], which indicated a mean delay in dental age of close to one year. Furthermore, they observed no significant effect of GH treatment on dental maturation. The lack of a subsequent therapeutic response would indicate that dental age is less affected by GH than craniofacial growth.

It thus appears that the increasing maturity of teeth and eruption requires further investigation. It can be assumed that the tooth maturation process and the eruptive movements of the tooth after crown formation are endocrinologically controlled [50].

The studies involved in our systematic review report that not only the height of GHD children, but also their craniofacial morphology and growth, are affected [43]. These studies support the previously demonstrated idea that the linear growth of the body is strongly correlated with jaw growth [49], and that the growth of craniofacial skeletal structures is poor in periods of slow longitudinal growth $[2,28,43-46]$.

Several linear craniofacial measurements have been found to be shortened in GHD patients, particularly the mandible and the cranial base [2,28,43-46]. In children with GH deficiency, it is the mandible that is small, especially the ramus length [2,43]. The most pronounced facial growth retardation is found for posterior face height [43].

Due to mandibular growth retardation, the mandible can be rotated backwards, and the dental-alveolar compensatory mechanism can be activated vertically in the anterior region, in order to maintain incisal contact for as long as possible [6]. It has been observed that males with GHD prior to treatment had a tendency to exhibit skeletal Class II [45]. However, Angle's Class II malocclusion was not as prevalent as expected given the retrognathic mandibular positions and reduced mandibular dimensions seen in many of the boys. This may be explained by the ability of the occlusion to adapt to slow changes during growth [28].

GH therapy induces the most pronounced catch-up growth within the first one to two years. Funatsu et al. [2] stated that GH therapy was started at a younger age in those in the long-term therapy group than in those in the untreated or short-term therapy groups. 
It was postulated that the GHD in the long-term therapy group was more severe than in the others. This is in agreement with the conclusion of Cantu et al. [27], which postulated that catch-up may depend not just on growth potential, but also on accumulated growth deficits at the beginning of growth hormone replacement therapy [52].

Dental caries have still not been extensively studied in GH-deficient children. Caries resistance was first suggested by Nikiforuk et al. [53], who concluded that the etiology of this condition most probably lay in the increased maturation time of enamel tissue before the eruption and the reduced exposure to environmental factors. The more recent study by Schroth et al. [54] reports that caries-free children were twice as likely to have optimal $25(\mathrm{OH}) \mathrm{D}$ concentrations $(>75 \mathrm{nmol} / \mathrm{L})$, and those with caries presented deficient levels ( $<35 \mathrm{nmol} / \mathrm{L})$. This was confirmed by Wójcik et al. [39,40], who related the lower prevalence of caries in GHD children the higher $25(\mathrm{OH})$ D level. It was concluded in those studies that an increase in vitamin D3 concentration by ten units decreased DMFT by 0.82 and DT by 0.66 . The relatively poor range of data on the level of caries in GHD patients suggests the need for further observations.

The occurrence of dental caries and tooth wear should be studied further in cases where the primary teeth remain longer in the oral cavity. After all, we know that the condition of the mineralized teeth tissues in both generally healthy patients and in those with GHD transfers across to the condition of the stomatognathic system. The healthier the masticatory organ, the better the condition of pediatric patients entering adulthood.

Birth age does not reflect fully the physiological development of a child. In order to closely evaluate the process of growth, it is necessary to use other criteria, such as dental age and skeletal age. These parameters are essential for dental providers to provide diagnoses and to plan therapy. In clinical practice, evaluation of both dental and skeletal age would be valuable in all children undergoing dental treatment, especially in those with GHD.

This study has several limitations. The first is the small number of GHD children examined in some of the studies, which makes the results difficult to compare. The studied groups differed in the number of participants, and sometimes the results of a much larger number of children were analyzed in the control group $[28,42,44,46]$. Although children with various medical conditions were excluded, the control groups did not only contain healthy children, and the comparison was made between the children both at the beginning of treatment and during treatment. The lack of information on the conditions of the dental examinations, especially regarding the qualifications of the examiners, makes the studies prone to bias. Our study search strategy was limited to English and Polish language papers from the last 20 years; this approach may have resulted in the omission of some reports, but it would be difficult to relate the results of studies conducted over twenty years ago to current conditions.

\section{Conclusions}

The available studies indicate that children with GHD showed abnormal craniofacial morphology with reduced mandibular dimensions, with a resulting tendency to Angle's Class II occlusion, which affected up to $31 \%$ of the patients. Dental age has been shown to be delayed in GHD patients by about 1 to 2 years. Moreover, the risk of dental caries in children with GHD decreases with increasing levels of vitamin D. The data are scarce and further studies would be valuable in evaluating the risk of various oral health problems and in organizing targeted dental care for this vulnerable group.

To gain more of an insight into the effects of this disease and its treatment on oral health and craniofacial structures, data need to be collected both before and after GH administration. Such longitudinal studies could help us to understand the complex endocrine mechanisms regulating the stomatognathic system's development and functions, in order to provide the optimal treatment of GHD-related disturbances. 
Author Contributions: Study concept and design: N.T.-W. and A.K. Collection of literature data: N.T.-W. and K.A.M. Analysis and interpretation of epidemiological data: N.T.-W., K.A.M. and J.O.-S. Drafting the manuscript: N.T.-W., K.A.M. and J.O.-S. Critical revision of the manuscript for important intellectual content: A.K. and J.O.-S. Study supervision: J.O.-S. and A.K. Funding acquisition: J.O.-S. All authors approved the manuscript. All authors have read and agreed to the published version of the manuscript.

Funding: The research was supported by the Poznan University of Medical Sciences (502-2022073190).

Institutional Review Board Statement: Not applicable.

Informed Consent Statement: Not applicable.

Data Availability Statement: Not applicable.

Conflicts of Interest: The authors declare no conflict of interest.

\section{References}

1. Almonaitiene, R.; Balciuniene, I.; Tutkuviene, J. Standards for permanent teeth emergence time and sequence in Lithuanian children, residents of Vilnius city. Stomatologija 2012, 14, 93-100.

2. Funatsu, M.; Sato, K.; Mitani, H. Effects of growth hormone on craniofacial growth. Duration of replacement therapy. Angle Orthod. 2006, 76, 970-977. [CrossRef]

3. Hikita, Y.; Yamaguchi, T.; Tomita, D.; Adel, M.; Nakawaki, T.; Katayama, K.; Maki, K.; Kimura, R. Growth hormone receptor gene is related to root length and tooth length in human teeth. Angle Orthod. 2018, 88, 575-581. [CrossRef]

4. Al-Kharobi, H.; El-Gendy, R.; Devine, D.A.; Beattie, J. The role of the insulin-like growth factor (IGF) axis in osteogenic and odontogenic differentiation. Cell Mol. Life Sci. 2014, 71, 469-476. [CrossRef]

5. Vallejo-Bolaños, E.; España-López, A.J.; Muñoz-Hoyos, A.; Fernandez-Garcia, J.M. The relationship between bone age, chronological age and dental age in children with isolated growth hormone deficiency. Int. J. Paediatr. Dent. 1999, 9, 201-206. [CrossRef]

6. Van Erum, R.; Mulier, G.; Carels, C.; de Zegher, F. Craniofacial growth and dental maturation in short children born small for gestational age: Effect of growth hormone treatment. Own observations and review of the literature. Horm. Res. 1998, 50, 141-146.

7. Davidopoulou, S.; Chatzigianni, A. Craniofacial morphology and dental maturity in children with reduced somatic growth of different aetiology and the effect of growth hormone treatment. Prog. Orthod. 2017, 18, 10. [CrossRef] [PubMed]

8. Litsas, G. Growth Hormone and Craniofacial Tissues. An update. Open Dent. J. 2015, 30, 1-8. [CrossRef] [PubMed]

9. Young, W.G.; Zhang, C.Z.; Li, H.; Osborne, P.; Waters, M.J. The influence of growth hormone on cell proliferation in odontogenic epithelia by bromodeoxyuridine immunocytochemistry and morphometry in the Lewis dwarf rat. J Dent Res. 1992, 71, 1807-1811. [CrossRef] [PubMed]

10. Li, H.; Bartold, P.M.; Zhang, C.Z.; Clarkson, R.W.; Young, W.G.; Waters, M.J. Growth hormone and insulin-like growth factor I induce bone morphogenetic proteins 2 and 4: A mediator role in bone and tooth formation? Endocrinology 1998, 139, 3855-3862. [CrossRef]

11. Vainio, S.; Karavanova, I.; Jowett, A.; Thesleff, I. Identification of BMP-4 as a signal mediating secondary induction beteen epithelial and mesenchymal tissues during early tooth development. Cell 1993, 75, 45-58. [CrossRef]

12. Tabata, M.J.; Fujii, T.; Liu, J.G.; Ohmori, T.; Abe, M.; Wakisaka, S.; Iwamoto, M.; Kurisu, K. Bone morphogenetic protein 4 is involved in cusp formation in molar tooth germ of mice. Eur. J. Oral. Sci. 2002, 110, 114-120. [CrossRef]

13. Smid, J.R.; Rowland, J.E.; Young, W.G.; Daley, T.J.; Coschigano, K.T.; Kopchick, J.J.; Waters, M.J. Mouse cellular cementum is highly dependent on growth hormone status. J. Dent. Res. 2004, 83, 35-39. [CrossRef] [PubMed]

14. Thesleff, I.; Keranen, S.; Jernvall, J. Enamel Knots as signaling centers linking tooth morphogenesis and odontoblast differentiation. Adv. Dent. Res. 2001, 15, 14-18. [CrossRef] [PubMed]

15. Oyanagi, T.; Takeshita, N.; Hara, M.; Ikeda, E.; Chida, T.; Seki, D.; Yoshida, M.; Seiryu, M.; Takano, I.; Kimura, S.; et al. Insulin-like growth factor 1 modulates bioengineered tooth morphogenesis. Sci. Rep. 2019, 9, 368. [CrossRef] [PubMed]

16. Arid, J.; Oliveira, D.B.; Evangelista, S.S.; Vasconcelos, K.R.F.; Dutra, A.L.T.; de Oliveira, S.S.; de Queiroz, A.M.; Nelson-Filho, P.; Vieira, A.R.; Küchler, E.C. Oestrogen receptor alpha, growth hormone receptor, and developmental defect of enamel. Int. J. Paediatr. Dent. 2019, 29, 29-35. [CrossRef] [PubMed]

17. Kazoullis, S.; Seow, W.K.; Holcombe, T.; Newman, B.; Ford, D. Common dental conditions associated with dental erosion in schoolchildren in Australia. Pediatr. Dent. 2007, 29, 33-39.

18. Opydo-Szymaczek, J.; Gerreth, K.; Borysewicz-Lewicka, M.; Pawlaczyk-Kamieńska, T.; Torlińska-Walkowiak, N.; Śniatała, R. Enamel defects and dental caries among children attending primary schools in Poznań. Poland. Adv. Clin. Exp. Med. 2018, 27, 1535-1540. [CrossRef]

19. Mejàre, I.; Axelsson, S.; Dahlén, G.; Espelid, I.; Norlund, A.; Tranæus, S.; Twetman, S. Caries risk assessment: A systematic review. Acta Odontol. Scand. 2014, 72, 81-91. [CrossRef]

20. Grunauer, M.; Jorge, A.A.L. Genetic short stature. Growth Horm. IGF Res. 2018, 38, 29-33. [CrossRef] [PubMed] 
21. Alatzoglou, K.S.; Webb, E.A.; Le Tissier, P.; Dattani, M.T. Isolated growth hormone deficiency (GHD) in childhood and adolescence: Recent advances. Endocr. Rev. 2014, 35, 376-432. [CrossRef] [PubMed]

22. Oświęcimska, J.; Roczniak, W.; Mikołajczak, A.; Szymlak, A. Growth hormone deficiency in children and young adults. Postepy Hig. Med. Dosw. 2016, 70, 928-937. [CrossRef] [PubMed]

23. Majewska, K.A.; Kedzia, A.; Kontowicz, P.; Prauzinska, M.; Szydlowski, J.; Switonski, M.; Nowacka-Woszuk, J. Polymorphism of the growth hormone gene GH1 in Polish children and adolescents with short stature. Endocrine 2020, 69, 157-164. [CrossRef] [PubMed]

24. Esposito, S.; Leonardi, A.; Lanciotti, L.; Cofini, M.; Muzi, G.; Penta, L. Vitamin D and growth hormone in children: A review of the current scientific knowledge. J. Transl. Med. 2019, 17, 87. [CrossRef] [PubMed]

25. Krukowska-Andrzejczyk, B.J.; Kalina, M.; Kalina-Faska, B.; Małecka-Tendera, E. Growth hormone therapy in children with partial growth hormone deficiency. Are we treating the right patients? Pediatr. Endocrinol. Diabetes Metab. 2020, 26, 65-72. [CrossRef]

26. Stolbizer, F.; Cripovich, V.; Paolini, A. Macrodontia associated with growth-hormone therapy: A case report and review of the literature. Eur. J. Paediatr. Dent. 2020, 21, 53-54. [CrossRef] [PubMed]

27. Cantu, G.; Buschang, H.; Gonzalez, J.L. Differential growth and maturation in idiopathic growth-hormone-deficient children. Eur. J. Orthod, 1997; 19, 131-139.

28. Kjellberg, H.; Beiring, M.; Wikland, K.A. Craniofacial morphology, dental occlusion, tooth eruption, and dental maturity in boys of short stature with or without growth hormone deficiency. Eur. J. Oral. Sci. 2000, 108, 359-367. [CrossRef]

29. Flores-Mir, C.; Mauricio, F.R.; Orellana, M.F.; Major, P.W. Association between growth stunting with dental age development and skeletal maturation stage. Angle Orthod. 2005, 75, 935-940.

30. Wites, M.; Kalukin, J.; Niżankowska-Jędrzejczyk, A.; Loster, B.W. Prediction of the growth spurt based on panoramic radiograhps. J. Stomatol. 2011, 64, 875-886.

31. Różyło-Kalinowska, I.; Kolasa-Raczka, A.; Kalinowski, P. Relationship between dental age according to Demirjian and cervical vertebrae maturity in polish children. Eur. J. Orthod. 2011, 33, 75-83. [CrossRef]

32. Kim, C.; Hong, Y.; Han, D.H.; Hong, H.K.; Kim, Y.N.; Bae, K.H. A prospective cohort study on emergence of permanent teeth and caries experience in Korean children. Int. J. Paediatr. Dent. 2011, 21, 254-260. [CrossRef]

33. Higgins, J.P.T.; Green, S. Cochrane Handbook for Systematic Reviews of Interventions; Version 5.1.0 (updated March 2011); The Cochrane Collaboration: London, UK, 2011.

34. Torlińska-Walkowiak, N.; Majewska, K.A.; Kędzia, A.; Opydo-Szymaczek, J. Clinical Implications of Growth Hormone Deficiency for Oral Health in Children: A Systematic Review. PROSPERO 2021, CRD42021250229. Available online: https://www.crd.york ac.uk/prospero/display_record.php?ID=CRD42021250229 (accessed on 24 May 2021).

35. Moher, D.; Liberati, A.; Tetzlaff, J.; Altman, D.G.; The PRISMA Group. Preferred reporting items for systematic reviews and meta-analyses: The PRISMA statement. PLoS Med. 2009, 6, e1000097. [CrossRef] [PubMed]

36. Methley, A.M.; Campbell, S.; Chew-Graham, C.; McNally, R.; Cheraghi-Sohi, S. PICO, PICOS and SPIDER: A comparison study of specificity and sensitivity in three search tools for qualitative systematic reviews. BMC Health Serv Res. 2014, 14, 579. [CrossRef] [PubMed]

37. Wells, G.; Shea, B.; O'Connell, D.; Peterson, J.; Welch, V.; Losos, M.; Tugwell, P. The Newcastle-Ottawa Scale (NOS) for Assessing the Quality If Nonrandomised Studies in Meta-Analyses. 2014. Available online: http://www.ohri.ca/programs/clinical_ epidemiology / oxford.asp (accessed on 24 March 2021).

38. Vivekanantham, A.; Edwin, C.; Pincus, T.; Matharu, M.; Parsons, H.; Underwood, M. The association between headache and low back pain: A systematic review. J Headache Pain. 2019, 20, 82. [CrossRef] [PubMed]

39. Wójcik, D.; Krzewska, A.; Szalewski, L.; Pietryka-Michałowska, E.; Szalewska, M.; Krzewski, S.; Pels, E.; Beń-Skowronek, I. Dental caries and Vitamin D 3 in children with growth hormone deficiency. Medicine 2018, 97, e9811. [CrossRef]

40. Wójcik, D.; Szalewski, L.; Pietryka-Michałowska, E.; Borowicz, J.; Pels, E.; Beń-Skowronek, I. Vitamin D3 and dental caries in children with growth hormone deficiency. Int. J. Endocrinol. 2019, 5, 1-8. [CrossRef]

41. Partyka, M.; Chałas, R.; Dunin- Wilczyńska, I.; Drohomyretska, M.; Klatka, M. Influence of growth hormone therapy on selected dental and skeletal system parameters. Ann. Agric. Environ. Med. 2018, 25, 60-65. [CrossRef] [PubMed]

42. Hodge, N.; Evans, C.A.; Simmons, K.E.; Fadavi, S.; Viana, G. Occlusal characteristics of individuals with growth hormone deficiency, idiopathic short stature, and russell-silver syndrome. J. Den. Child. 2015, 82, 135-140.

43. Kim, K.B.; Kim, E.K.; Jang, K.M.; Kim, M.S.; Park, E.Y. Evaluation of craniofacial morphology in short-statured children: Growth hormone deficiency versus idiopathic short stature. Yeungnam Univ. J. Med. 2021, 38, 47-52. [CrossRef]

44. Preda, S.A.; Albulescu, D.M.; Mitroi, M.R.; Popescu, M.; Nechita, F.; Camen, A.; Cotoi, I.A. Craniofacial morphology aspects in children with isolated growth hormone deficiency-A cephalometric study. Rom. J. Morphol. Embryol. 2019, 60, 653-658.

45. Choi, S.-H.; Fan, D.; Hwang, M.S.; Lee, H.K.; Hwang, C.J. Effect of growth hormone treatment on craniofacial growth in children: Idiopathic short stature versus growth hormone deficiency. J. Formos. Med. Assoc. 2017, 116, 313-321. [CrossRef]

46. Segal, D.G.; Pescovitz, O.H.; Schaefer, G.B.; DiMeglio, L.A. Craniofacial and acral growth responses in growth hormone-deficient children treated with growth hormone. J. Pediatr. 2004, 144, 437-443. [CrossRef]

47. Almond, J.R.; Leroux, B.G.; Knight, D.; Ramsay, D. Craniofacial morphology and tooth wear:a longitudinal study of orthodontic patients. Angle Orthod. 1999, 69, 7-13. 
48. Marinelli, A.; Alarashi, M.; Defraia, E.; Antonini, A.; Tollaro, I. Tooth wear in the mixed dentition: A comperative study between children born in the 1950's and the 1990's. Angle Orthod. 2005, 75, 340-343.

49. Martignon, S.; López-Macías, A.M.; Bartlett, D.; Pitts, N.; Usuga-Vacca, M.; Gamboa, L.F.; O’Toole, S. The use of index teeth vs. full mouth in erosive tooth wear to assess risk factors in the diet: A cross-sectional epidemiological study. J. Dent. 1031.

50. Kjaer, I. Mechanism of human tooth eruption: Review article including a new theory for future studies on the eruption process. Scientifica 2014, 2014, 341905. [CrossRef] [PubMed]

51. Leroy, R.; Cecere, S.; Lesaffre, E.; Declerck, D. Variability in permanent tooth emergence sequences in Flemish children. Eur. J. Oral Sci. 2008, 116, 11-17. [CrossRef] [PubMed]

52. Kedzia, A.; Majewska, K.A.; Korcz, M. Do the intervals in growth hormone therapy positively affect the growth velocity? Pediatr. Endocrinol. Diabetes Metab. 2020, 26, 113-117. [CrossRef] [PubMed]

53. Nikiforuk, G.; Frasier, S.D.; Thompson, G.W. Increased Caries Resistance in Primary Dentitions in Children with Growth Hormone Deficiency. J. Dent. Res. 1971, 50, 2. [CrossRef]

54. Schroth, R.J.; Levi, J.A.; Sellers, E.A.; Friel, J.; Kliewer, E.; Moffatt, M.E. Vitamin D status of children with severe early childhood caries: A case-control study. BMC Pediatr. 2013, 13, 1-8. [CrossRef] 